УДК: 355.23(477):378.5

Олександр Юрійович Пермяков (доктор технічних наук, професор)

Олексій Анатолійович Кільменінов (кандидат технічних наук)

Ярослав Вячеславович Мельник

Національний університет оборони Украӥни імені Івана Черняховського, Київ, Украӥна

\title{
ЗАСТОСУВАННЯ ПЕРКОЛЯЦІЙНИХ АЛГОРИТМІВ ДЛЯ ОЦІНКИ НАДІЙНОСТІ ГЕТЕРОГЕННИХ МЕРЕЖ ВІЙСЬКОВОГО ПРИЗНАЧЕННЯ
}

В останні роки, особливо з початком агресії Російської Федерації проти України, значно зросли вимоги до надійності існуючих інформаційно-комунікаційних систем (гетерогенних мереж), як технологічної основи системи управління з'єднань, об'єднань та органів військового управління всіх рівнів Збройних Сил Украӥни. Адже вихід з ладу лише одного елемента існуючої системи управління (в наслідок навмисних (кібератак) або ненавмисних перешкод може призвести до втрати системи управління в иілому. Тому створення надійної інформаційно-комунікаційної мережі (ІКМ) для забезпечення функціонування системи управління є актуальним та важливим завданням. Як результат автори пропонують для оиінки надійності гетерогенних мереж (ГМ) розглядати передачу інформації у середині мережі як проходження пакетів даних, з одного сегменту ГМ в інший через інфраструктуру провайдерів (мережу Інтернет), за допомогою перколяційних алгоритмів (алгоритмів, побудованих на моделях теорії перколяиії). У 1956 роиі у статmі "Percolation processes I. Crystals and mazes" (Проиес протікання. Кристали та лабіринти) автори S.R.BROADBENT ma J.M.HAMMERSLEY запропонували моделювати протікання речовини в пористому матеріалі за допомогою методу Монте-Карло. Подальші дослідження в иій області показали, щзо використання даного підходу може застосовуватися в різних галузях науки, таких, як фізика (статистична), матеріалознавство, економіка, хімія, геологія, соиіологія, медицина, для опису виникнення зв'язаних структур у випадкових середовищах (кластерів) випадкових середовищах (кластерів), що складаються з окремих елементів. У даній статті автори пропонують результати досліджень застосовування перколячійних алгоритмів для очінки надійності гетерогенних мереж військового призначення.

Ключові слова: гетерогенна мережа; локальна обчислювальна мережа органу управління; теорія перколячіï; методика; комунікаційні мережі загального користування; навмисні та ненавмисні перешкоди.

\section{Вступ}

Для гарантованого функціонування системи управління потрібен новий підхід до оцінки надійності гетерогенних мереж, який би забезпечив безперебійне функціонування мережі.

Забезпечення високої надійності сучасних гетерогенних мереж 3 одночасним зниженням матеріальних та фінансових витрат є актуальним проблемним питанням для системи управління з'єднань, об'єднань та органів військового управління ЗСУ.

Постановка проблеми. Для передачі інформації між елементами ГМ застосовується сімейство протоколів TCP/IP та UDP. В даних протоколах описується формат пакету повідомлень, переданих між вузлами. У протоколах IPv4 i IPv6 закладена можливість вказувати проміжні вузли маршруту, при цьому, яким саме способом визначаються вузли маршруту не розкривається. В сучасних методах побудови ГМ при виборі альтернативних структур зв'язку абонентів, не враховуються параметри впливу навмисних та ненавмисних перешкод (ННП), що часто приводить до вибору структури низької надійності до впливу ННП. При цьому збільшення кількості вузлів зв'язку в ГМ приводить до відносного зниження достовірності результатів порівняльної оцінки надійності. Також сучасні гетерогенні мережі включають в себе елементи системи зв'язку загального користування, що у свою чергу призводить до наявності в інтегрованій комп'ютерній мережі значного числа елементів, для яких неможливо здійснювати моніторинг 
параметрів функціонування та коригуючий вплив (тобто неможливо їх контролювати).

Аналіз останніх досліджень і публікацій. Аналіз останніх досягнень в області комп'ютерних мереж для забезпечення надійності інформаційних процесів у Міністерстві оборони та Збройних Силах України показав, що згідно з класифікаціям такі мережі, в основному, побудовані за клієнтсерверною архітектурою. За призначенням - це інформаційно-керуючи системи, системи підтримки прийняття рішень, інформаційнопошукові або інформаційно-довідкові системи, системи обробки даних. За структурою апаратного забезпечення - це системи з віддаленим доступом або мережи ЕОМ. За характером обслуговування користувачів їх можна віднести до систем колективного використання.

Метою статті $\epsilon$ удосконалення існуючих методів оцінки надійності гетерогенних мереж за допомогою теорії перколяції, що у свою чергу дозволить будувати більш стійку до ННП мережі.

\section{Виклад основного матеріалу дослідження}

Зазвичай ГМ може бути представлена у вигляді графу або регулярної решітки, побудованої за певними імовірнісними закономірностями (безмасштабні мережі, тощо). Припустимо, у якийсь пористий матеріал (хімія, фізика) 3 однієї сторони заливають рідину, і чекають чи просочиться ця рідина через пори до протилежної сторони чи ні? Якщо представити, що пористий матеріал - це гетерогенна мережа, а рідина - це пакети даних, то за допомогою математики дану задачу можна змоделювати тривимірною моделлю на решітці розміром $n * n * n$ вузлів. Вузли, які перебувають рядом, зв'язані між собою шляхами, які з імовірністю $р$ відчинені. При цьому виникає запитання існування в системі (3 імовірністю $p$ ) наскрізного ланцюжка відчинених шляхів, який отримав назву перколяційного зв'язку. Схожим чином сформулюємо задачу перколяції вузлів. Припустимо, що вузол може бути задіяний 3 імовірністю $p$, яка імовірність існування наскрізного графу, або при якому значенні $p$ незадіяні вузли стануть незв'язаними? Задачу можна розв'язувати для регулярної решітки будь-яких розмірів, але не можуть бути застосовані в обраній предметній області гетерогенних мереж без адаптації 3 наступних причин:

- гетерогенні мережі не можуть бути представлені у вигляді регулярних решіток, а граф не має чіткого визначення “початку” і “кінця";

- гетерогенні мережі містять у собі обладнання великої кількості провайдерів (організацій, які надають послуги доступу та передачі (інформації) певними інформаційними каналами). При цьому кількість елементів у цих мережах не перевищує декількох тисяч. При такій, відносно не великій кількості, неможливе представлення мережі у вигляді безмасштабних графів.

При передачі інформації немає необхідності відповідати на запитання, при яких умовах пакети 3 цією інформацією будуть передані на значну кількість елементів мережі.

Як зазначено вище (табл. 1), у теорії перколяції добре вивчені регулярні та довільно-масштабовані графи (критичні значення доказав Гаррі Кестен), а також нескінчені решітки. [1]. Регулярні графи (такі як квадратні та кубічні решітки) мають практичне застосування у багатьох областях науки. На цих графах, за допомогою теорії перколяції, описуються процеси фазового переходу в електропровіднику, дифузійні та інші процеси. [2]. При цьому решітки генеруються по заздалегідь визначених алгоритмах, як правило, шар за шаром. Це дозволяе виділити границі решіток, при цьому, наявність вузлів з яких у кластері визначає, є кластер перколяційний чи ні, а також створювати структури 3 величезною кількістю вузлів.

Безмасштабні графи та нескінченні решітки вивчаються в рамках соціальних наук, епідеміології (у випадку коли ймовірність зараження вірусом перевищує граничне значення, кількість заражених людей стає нескінченно великою (утворюється перколяційний кластер) i можна говорити про епідемію) та комп'ютерної вірусології.

Таблиця 1

Числове значення порігу перколяції для регулярних решіток

\begin{tabular}{|c|c|c|}
\hline Решітка & Назва решітки & $\begin{array}{l}\text { Критичне } \\
\text { значення }\end{array}$ \\
\hline$(4,6,12)$ & & 0,7478 \\
\hline$\left(6^{\mathrm{a}}\right)$ & Гексагональна & 0,697 \\
\hline$(3,6,3,6)$ & Кагоме & 0,6527 \\
\hline$(3,4,6,4)$ & & 0,6281 \\
\hline$\left(4^{4}\right)$ & Квадратна & 0,5927 \\
\hline$\left(3^{4}, 6\right)$ & & 0,5793 \\
\hline$\left(3^{2}, 4.3,4\right)$ & Пазл & 0,5508 \\
\hline$\left(3^{3}, 4^{2}\right)$ & & 0,5502 \\
\hline$\left(3^{6}\right)$ & Трикутна & 0,5 \\
\hline
\end{tabular}

Широке застосування для цих робіт мають модулі SIS та SIR (Susceptible (підвернений зараженню вузол), Infected (інфікований), Removed (видалений, отримав імунітет)). 
Перехід вузла 3 одного стану в інший описується кінцевим автоматом. Сучасні дослідники додають нові параметри в моделі SIS/SIR. Наприклад, стан “пильність користувача" у моделях поширення комп'ютерних вірусів. У цьому стані користувач комп'ютера підвищує свою увагу до вірусів та ймовірність зараження падає.

На відміну від вищезазначених та добре вивчених вищезазначених решіток, які побудовані за загальновідомим правилами, реальні структури ГМ не мають регулярної структури та структури, яка задається певними правилами, що не дозволяє знайти узагальнене аналітичне рішення.

В ГМ під перколяціійним кластером визначається кластер, що складається із працездатних, зв'язаних між собою, лініями зв'язку елементів, який містить у собі хоча б по одному граничному вузлу 3 кожної територіально розподіленою ЛОМ ГМ. Граничні вузли $K=\left\{\mathbf{k}_{\tilde{1}}\right\}$ це елементи ЛОМ ГМ, за допомогою яких ЛОМ ГМ інтегруються 3 мережею Інтернет. [3]. При цьому уся сукупність вузлів на одній ЛОМ утворює межі, 3 яких визначається множина меж M.[4]:

$$
\mathrm{M}=\left\{m_{\mathrm{f}}\right\}_{,} m_{\tilde{f}} \subset k_{\mathrm{i} x}\left|m_{\mathrm{f}}\right|>0,|M| \geq 2
$$

де $m-$ межа, $k$ - ключовий вузол. Один ключовий вузол належить тільки одній границі $n_{\tilde{f}} m_{\tilde{f}}=\emptyset$. При цьому кластер $\boldsymbol{Y}$ вважається перколяційним у тому і тільки в тому випадку, якщо він містить хоча б по одному вузлу з кожної границі:

$$
Y \mathrm{n}_{j} m_{j} \neq \emptyset \text {. }
$$

Імовірність збереження зв'язку $p_{\mathrm{sa}}$ між територіально розподіленими сегментами ГМ в умовах впливу навмисної або ненавмисної перешкоди за певний інтервал часу, протягом якого вузли, які вийшли з ладу не можуть бути відновлені, визначається як імовірність того, чи збережеться зв'язок між множинами граничних вузлів ГМ, через які здійснюється інтеграція 3 Інтернет.

Узагальнений алгоритм представлений на рис. 1.

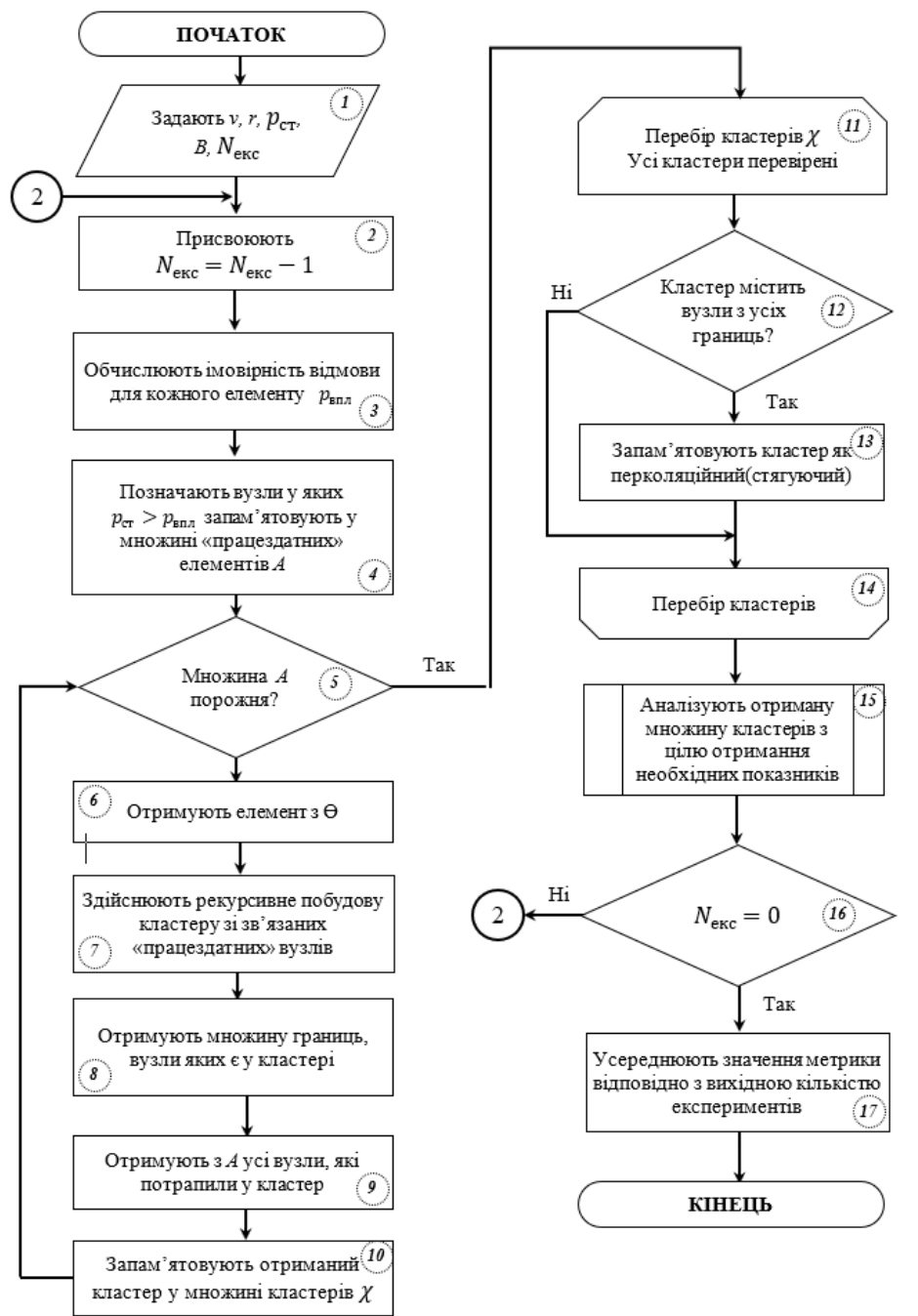

Рис. 1. Блок-схема (узагальнена) алгоритму визначення послідовності дії для реалізації розрахунків метрик методу 
Задаємо вихідні дані (блок 1 рис. 1). Структура ГМ представляється у вигляді графу, вузлами $v$ якого $€$ елементи мережі, а ребрами $r$ - зв'язки між ними. Вузли локальних сегментів, за допомогою яких здійснюється інтеграція з мережею Інтернет, визначають множину множин $B$ відповідно до формули (1). Задається імовірність стійкості $p_{c m}$ вузлів до впливу перешкоди, яка $є$ загальною для всіх вузлів мережі. [5]. Визначається кількість експериментів $N_{\text {екс }}$ яка може бути обчислена за формулою:

$$
N_{\text {erc }} \approx \varepsilon^{2} /\left(p_{\mathrm{er}} \sigma^{2}\right)
$$

За допомогою системи множин, що не перетинаються, одержують множину кластерів, які складаються зі зв'язаних між собою працездатних вузлів. Тривіальна реалізація може бути наступною. Вибирають перший вузол із множини A (бл. 6 рис. 1). Будують множину А, яка складається 3 цього вузла. Вузол видаляють із $\mathrm{A}$ (бл. 9 рис. 1). Для кожного доданого в $\alpha$ вузла рекурсивно викликається дана процедура доти, поки є зв'язані $з$ черговим вузлом вузли (бл. 7 рис. 1). Після повторення $\alpha_{1}$ переходять до побудови $\alpha_{\mathrm{i}}$ доти, поки А не стане порожнім (бл. 5 рис. 1). При побудові $\alpha_{\mathrm{i}}$ для кожного вузла
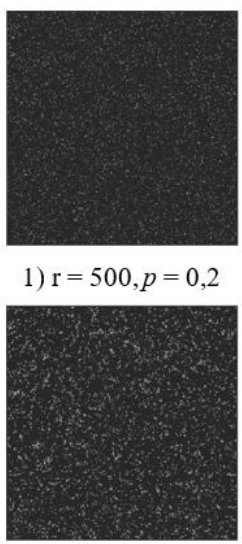

5) $r=250, p=0,2$

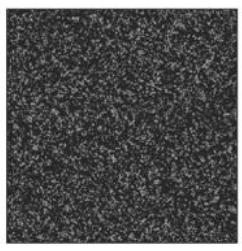

9) $r=100, p=0,2$

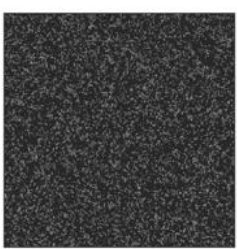

2) $r=500, p=0,55$

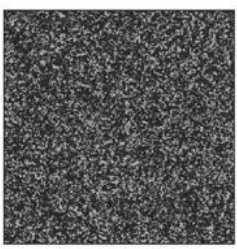

6) $r=250, p=0,55$

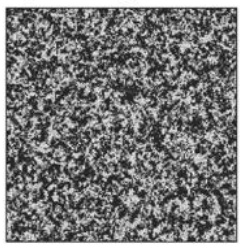

10) $r=100, p=0,55$ де $\sigma$ - відносна погрішність, $\varepsilon$ корінь рівняння

$$
\sqrt{\frac{2}{\pi}} \int_{0}^{z} \exp -\frac{x^{2}}{2} d x=\beta
$$

де $\beta$ - необхідна достовірність.

Зменшують значення $\boldsymbol{N}_{\text {екс }}$ на 1 (бл. 2 рис. 1). Кожному вузлу мережі незалежно від інших встановлюється $p_{\text {впл }}$, яке визначається за рівномірним законом розподілу (бл. 3 рис. 1). Вузли, у яких $p_{c n}>p_{\text {gnn }}$, запам'ятовують у множині працездатних вузлів A , здатних передавати трафік. перевіряється, належить він якій-небудь границі, i якщо так, зберігають ідентифікатор границі. Зберігають усі отримані кластери $\alpha$ у множині кластерів $\chi$ (бл.10 рис. 1).

Перебирають усі кластери 3 множини $\chi$ (бл. 1114 рис.1) і перевіряють, чи містить кластер вузли 3 усіх границь (бл. 12 рис.1). Якщо кластер містить хоча $б$ по одному вузлу з кожної границі, його зберігають у множині перколяційних кластерів П.

Даний критерій відбору перколяційних кластерів відповідає наведеному вище визначенню (рис. 2) (де чорним колір - вузли, що вийшли 3 ладу, сірим стійкі до впливу вузли, білі перколяційний кластер).
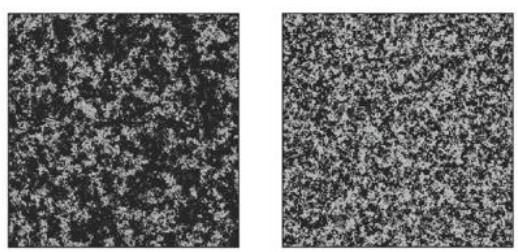

4) $r=500, p=0,65$
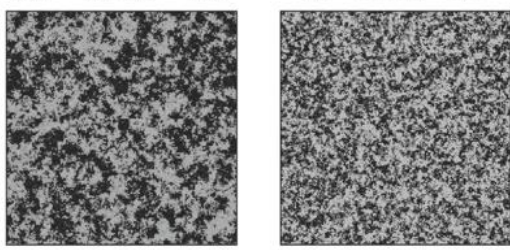

7) $r=250, p=p_{\text {зб }}$

8) $r=250, p=0,65$

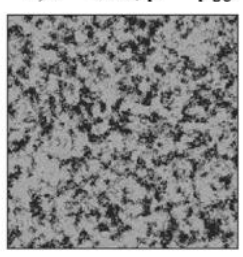

11) $r=100, p=p_{\text {зб }}$

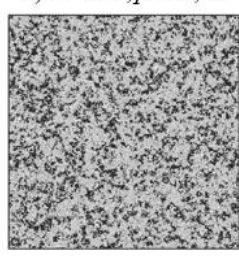

12) $r=100, p=0,65$

Рис. 2. Залежність збереження перколяційного кластеру від імовірності стійкості $p$ та незалежність від розміру решітки $r$.

Далі множина П аналізується і отримуються потрібні метрики (бл. 15 рис. 1): оцінки розміру працездатного кластеру, імовірність збереження зв'язку між границями локальних сегментів, імовірність зв'язку між випадково обраним вузлом IKM і границями локальних сегментів.

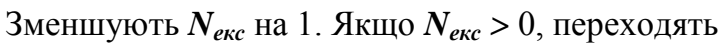
на крок 2 (бл. 16 рис.1). Інакше $\left(N_{\text {екс }}=0\right)$ усереднюють отримані на кожному кроці метрики та закінчують виконання алгоритму (бл. 17 рис. 1).

Висновки і перспективи подальших досліджень 
Створення сучасних гетерогенних мереж, як технологічної основи системи управління з'єднань, об'єднань та органів військового управління всіх рівнів Збройних Сил України, неможливе без інтеграції ї телекомунікаційними мережами загального користування 3 економічних і технічних причин. Це призводить до наявності в інтегрованій комп'ютерній мережі значного числа елементів, для яких неможливо здійснювати моніторинг параметрів функціонування та здійснювати коригуючий вплив (тобто неможливо їх контролювати). Особливим фактором, який необхідно враховувати, є вплив навмисних та не навмисних перешкод.

Аналіз існуючих методів забезпечення надійності гетерогенних мереж [6] показав, що вони не пристосовані для мереж, що включають в себе елементи системи зв'язку загального користування, під час проектування та експлуатації мережі. Методи оцінки надійності, що існують, не враховують наявність не підконтрольних власнику ГМ елементів, що функціонують в умовах впливу ННП і тим самим не дозволяють створити модель ГМ, яка підходить для забезпечення достовірної оцінки надійності.

\section{Лimepamypa}

1.Cristopher Мооге and M. E. J. Newman. Epidemics and percolation in small-world networks. Phys. Rev. E, 61(5):5678-5682, May 2000. 2. Raissa DSouza. Percolation and epidemiology on networks. lection, jan. 3. Cliff C. Zou, Don Towsley, Weibo Gong. Email virus propagation modeling and analysis. Technical Report TR-CSE-03-04, Univ. Massachusetts, 2003. 4. Xiao F. Wang and Guanrong Chen. Complcx networks: small-world, scalc-free and beyond. Circuits and Systems Magazine, IEEE, 3(1):6-20, 2003. 5. Ушаков И.А. Надежность
Резервування ресурсів є дорогим варіантом і не скасовує необхідності порівняльного аналізу надійності різних варіантів ГМ, що одержуються в результаті підключення тієї чи іншої схеми резервування [7].

Методами забезпечення надійності, які найбільше використовуються, $є$ маршрутизація та методи забезпечення якості обслуговування. Ці методи мають ряд суттєвих недоліків, а саме істотне підвищення складності аналізу системи із зростанням кількості елементів в ній.

Авторами запропоновано представляти процес передачі інформації в гетерогенній мережі як процес просочування речовини (інформаційних пакетів) через мережу. Розглянута теорія перколяції, що вивчає подібні процеси. Робиться висновок, що теорія перколяції може бути використана для удосконалення існуючих підходів до оцінки надійності гетерогенних мереж, шляхом визначення границь - вузлів територіально розподілених локальних сегментів ГМ, за допомогою яких здійснюється підключення до мереж зв'язку загального користування.

\title{
ПРИМЕНЕНИЕ ПЕРКОЛЯКИОННЫХ АЛГОРИТМОВ ДЛЯ ОЦЕНКИ НАДЕЖНОСТИ ГЕТЕРОГЕННЫХ СЕТЕЙ ВОЕННОГО НАЗНАЧЕНИЯ
}

\author{
Александр Юрьевич Пермяков (доктор технических наук, профессор) \\ Алексей Анатольевич Кильменинов (кандидат технических наук) \\ Ярослав Вячеславович Мельник
}

\section{Национальный университет обороны Украины имени Ивана Черняховского, Киев, Украина}

В последние годы, особенно с началом агрессии Российской Федерации против Украинь, значительно возросли требования к надежности существующих информационно-коммуникационных систем (гетерогенных сетей), как технологической основы системы управления соединений, объединений и органов военного управления всех уровней Вооруженных Сил Украины. Ведь выход из строя только одного элемента существующей системы управления (вследствие умышленных (кибератак) или непреднамеренных помех) может привести к потере системь управления в целом. Поэтому создание надежной информаџионно-коммуникационной сети (ИКМ) для обеспечения функиионирования системь управления является актуальной и важной задачей. В результате авторы предлагают для оценки надежности ГМ усовершенствовать существующий метод, в котором передача информации внутри сети рассматривается как прохождение пакетов данных, с одной Modern Information Technologies in the Sphere of Security and Defence № 1(34)/2019ＩSSNV2311-7249(Print)/ISSNV2410-7336(Online) $\quad 27$ 
сегмента ГМ в другой через инфраструктуру провайдеров (Интернет), с помощзью перколяционных алгоритмов (алгоритмов построенных на моделях теории перколячии). В 1956 году в статье "Percolation processes I. Crystals and mazes" (прочесс протекания. Кристалль и лабиринты) авторы S.R.BROADBENT и J.M.HAMMERSLEY предложили моделировать протекания вещества в пористом материале с помощью метода Монте-Карло. Дальнейшие исследования в этой области показали, что использование данного подхода применяется в различных областях науки, таких, как физика (статистическая), материаловедение, экономика, химия, геология, сочиология, медицина, для описания возникновения связанных структур в случайных средах (кластеров) случайных средах (кластеров), состоящие из отдельных элементов.

Ключевые слова: гетерогенная сетьж; локальная вычислительная сеть органа управления; теория перколяции; методика; коммуникационные сети общего пользования; умышленные и неумышленные помехи.

\title{
APPLICATION OF PERCOLATION ALGORITHMS FOR ASSESSING THE RELIABILITY OF HETEROGENEOUS NETWORKS OF MILITARY USE
}

\author{
Oleksandr Permiakov (Doctor of technical sciences, professor) \\ Oleksii Kilmeninov (Candidate of technical sciences) \\ Yaroslav Melnyk
}

\section{National Defence University of Ukraine named after Ivan Cherniakhovsky, Kyiv, Ukraine}

In recent years, especially with the onset of aggression by the Russian Federation against Ukraine, the requirements for the reliability of existing heterogeneous networks as the technological basis of the command and control system of formations, unions and military control bodies of all levels of the Armed Forces of Ukraine have significantly increased. Indeed, the failure of only one element of the existing control system (due to deliberate (cyber-attacks) or unintentional interference) can lead to the loss of the control system as a whole. Therefore, the creation of a reliable heterogeneous network (GM) to ensure the functioning of the control system is an important and important task. As a result, the authors propose, in order to assess the reliability of the GM, to improve the existing method, in which information transfer within the network is viewed as passing data packets from one GM segment to another through the providers infrastructure (Internet), using percolations algorithms (algorithms build on percolation theory models). In 1956, in the article "Percolation processes I. Crystals and mazes" (flow process. Crystals and labyrinths) authors S.R. BROADBENT and J.M. HAMMERSLEY proposed to simulate the flow of matter in a porous material using the Monte Carlo method Further research in this area showed that the use of this approach is used in various fields of science, such as physics (statistical), materials science, economics, chemistry, geology, sociology, medicine, to describe the occurrence of related structures in random environments (clusters) of random environments. (clusters), consisting of individual elements.

Key words: heterogeneous network; local area network of a management body; percolation theory; methods; public telecommunication networks; intentional and unintentional interference.

\section{References}

1.Cristopher Мооге and M. E. J. Newman. Epidemics and percolation in small-world networks. Phys. Rev. E, 61(5):5678-5682, May 2000. 2. Raissa DSouza. Percolation and epidemiology оп networks. lection, jan. 3. Cliff C. Zou, Don Towsley, Weibo Gong. Email virus propagation modeling and analysis. Technical Report TR-CSE-03-04, Univ. Massachusetts, 2003. 4. Xiao F. Wang and Guanrong Chen. Complcx networks: small-world, scalc-free and beyond. Circuits and Systems Magazine, IEEE, 3(1):6-20, 2003. 5. Ushakov I.A.
Reliability of technical systems. M.: - Radio and communication, 1985. 608c. 6. Matei Ripeanu, Ian Foster, and Adriana Iamnitchi. Mapping the gnutella network: Properties of large-scale pcer-to-peer systems and implications for system. IEEE Internet Computing Journal, 6:2002, 2002 7. Puchkov O.O., Zinchenko A.O., Romaschenko R.A. Estimation of the possibility of using Frame relay technology in telecommunication networks of special purpose . К.: ВITI НТУ “КПI”,2010. 124-125. 